\title{
MAFIC DIKE SWARMS OF THE GOIÁS MASSIF. CENTRAL BRAZIL.
}

\author{
RAUL MINAS KUYUMJAN*
}

\begin{abstract}
RESUMO
OS ENXAMES DE DIQUES MÁFICOS DO MACIÇO DE GOIÁS, BRASIL CENTRAL. Relações de campo e litogeoquímica permitiram indivualizar três enxames de diques máficos no Maciço de Goiás. O enxame mais antigo compreende diques que secionam terrenos granhóide-gi-eenstone, são recobertos por rochas mctassedimentares proterozóicas e foram metamorfisados nas fácies xisto verde ou anfibolito. Esses diques mostram concentrações de $\mathrm{TiO}_{2}$ inferiores a $2 \%$ e apresentam similaridade química com basaltos do tipo N-MORB. Diques não metamorfisados, mas localmente cisalhados, secionam rochas arqueanas e proterozóicas do Macico de Goias e foram posicionados, provavelmente, nos estágios finais de deformação do Ciclo Brasiliano ( $600 \mathrm{Ma})$. Esses diques apresentam concentrações de $\mathrm{TiO}_{2}$ entre 2 e $3 \%$ e são quimicamente semelhantes aos basaltos continentais da província do Deccan. O enxame de idade mais recente compreende diques sem deformação ou metamorfismo, mais ricos em $\mathrm{TiO}_{2}(>3 \%)$ e com composição química também semelhante aos basaltos do Deccan. $\mathrm{O}$ posicionamento destes diques ocorreu, provavelmente, no Mesozóico, durante a fragmentação do Gondwana.
\end{abstract}

Palavras-chave: Diques máficos, geoquímica, Maciço de Goiás, Brasil.

\begin{abstract}
Three mafic dike swarms occur in the Goiás Massif. The earliest dikes cut Archaean granitoid-greenstone terranes partially overlain by Proterozoic metasedimentary units, underwent metamorphism of the greenschist to amphibolite fácies and consist of low-titanium $\left(<2 \% \mathrm{TiO}_{2}\right)$ basaltic rocks chemically similar to N-MORB. Unmetamorphosed but locally sheared dikes cut archaean and proterozoic rocks, have 2 to $3 \% \mathrm{TiO}_{2}$ and are more like Deccan continental flood basalts. They were probably emplaced during the late stage of the Brasiliano cycle. Younger mafic dikes of the Goiás Massif are unmetamorphosed and undeformed, enriched in $\mathrm{TiO}_{2}(>3 \% 0)$ and chemically similar to Deccan continental flood basalts. The emplacement of these dikes was probably related to the fragmentation of Gondwana during Mesozoic. The geochemical similarities between the Neoproterozoic and Mesozoic dikes of the Goiás Massif support the inference that the geochemical features of the Mesozoic mantle were inherited frorrï processes that occurred during the Proterozoic.

Keywordsi mafic dikes, geochemistry, Goiás Massif, Brazil.
\end{abstract}

INTRODUCTION Although mafic dikes of at least two generations are acommon feature of the Precambrian crust of the Goiás Massif terrane, central Brazil, where they form swarms with a high dike densily (Figure 1) they have receivcd only cursory attention (Sial et al. 1984, Fuck et al. 1985). In recent years there hás been increasing interest in the distribution, classification, geochemistry, and petrology of the Proterozoic dike swarms of the Goiás Massif (Kuyumjian 1991, Girardietal. 1992, Valente \& Kuyumjian 1993andTomazzoli \& Nilson 1994).

The oldest regional rocks are chiefly represented by $\mathrm{Ar}$ chaean high-grade granitoid-gneisses and low-grade granitegreenstone terranes cut by metamorphosed mafic subvertical dikes striking NE-SW, NW-SE and less frequently E-W. These dikes are deformed, faulted, and recrystallized. Their widths range from a few centimeters to about 80 meters. Individual dikes can be traced along strike up to $20 \mathrm{~km}$ and frequently show displacements due to local faulting. These dikes intersect granitoid nuclei of the Archaean granite-greenstone terrane and adjacent granitoid gneisses,,and are partially overlain by Proterozoic metasedimentary-ujiits, suggesting that they were probably intruded during íhe late Archaean and/or early Proterozoic. Some of these dikes terminate abruptly within the greenstone belts, after cutting the contact with the neighboring granitoids.

Unmetamorphosed and undeformed, but locally sheared E-W, NE-SW and less frequently N-S striking dikes range from a few centimeters to tens of meters in width and are several tens of meters to about $80 \mathrm{~km}$ long. These dikes deform and displace previous dikes, crossciU the Archaean terrane, the middle to Neoproterozoic Grupo Paranoá metasedimentary rocks, the Middle-Upper Proterozoic Araxá Group metasediments in the Pirenópolis region and the Neoproterozoic Mara Rosa volcano-sedimentary sequence. In shear zones, original textures are destroyed, and the rock is reduced to intensely foliated, fine-grained schist. According to Araújo Filho (1992), these shear zones are related to the regional compressive episode at the end of the Neoproterozoic Brasiliano event.
These data indicate that the intrusion of the dikes probably dates back to the early Braziliano Orogeny (-800 Ma).

The younger mafic dikes from Goiás are the best preserved. They postdate ali the Precambrian rocks and have not bcen affected by any deformations. Individual dikes typically exceed $30 \mathrm{~m}$ in width and some can be traced for distances of upto $100 \mathrm{~km}$.

To charactcrize the chemistry of the Massif of Goiás mafic dike swarms, 70 samples were collected from forty outcrops.

\section{PETROGRAPHY AND CLASSIFICATION The} metamorphosed mafic rocks are fine to médium amphibolites composed predominantly of an assemblage of amphibole, plagioclase, and magnetite/ilmenite. Nearly ali dikes commonly contain up to $5 \%$ quartz. Their mineral assemblages indicate greenschist (actinolite, albite-oligoclase, quartz, garnet and magnetite/ilmenite) and amphibolite (hornblende, andesine, quartz, epidote and magnetite/ilmenite) fácies. Less metamorphosed dikes, locally contain actinolite around relics of clinopyroxene crystals. Sphene, apatite, biotite, and zircon are accessory minerais. Coarse-grained dikes locally contain quartz-alkali feldspar intergrowths. Holocrystalline textures prevail over slightly porphyritic textures.

The unmetamorphosed dikes consist of diabase, have subophitic texture and they are composed of plagioclase (andesina-labradorita), augite and minor opaque mineral. When sheared, the primary mineral assemblage is variably transformed to hornblende, oligoclase-andesine, quartz, biotite, epidote, sphene and opaque minerais.

Typical younger mafic dikes of the Goiás Massif are finegrained, have subophitic to ophitic texture, and are olivine- to quartz-diabase composed mainly of andesine-labradorite, diopside, hyperstene and rare augite, with ilmenite, pyrite, apatite and rare olivine as accessories.

On a CIPW normative basis, the distribution of the metamorphosed dikes in the R 1-R2 diagram of De La Roche et al. (1980) are andesi-basalt and tholeiite, while the unmetamorphosed and younger dikes are andesi-basalt, andesite and olivine-tholeiite. 

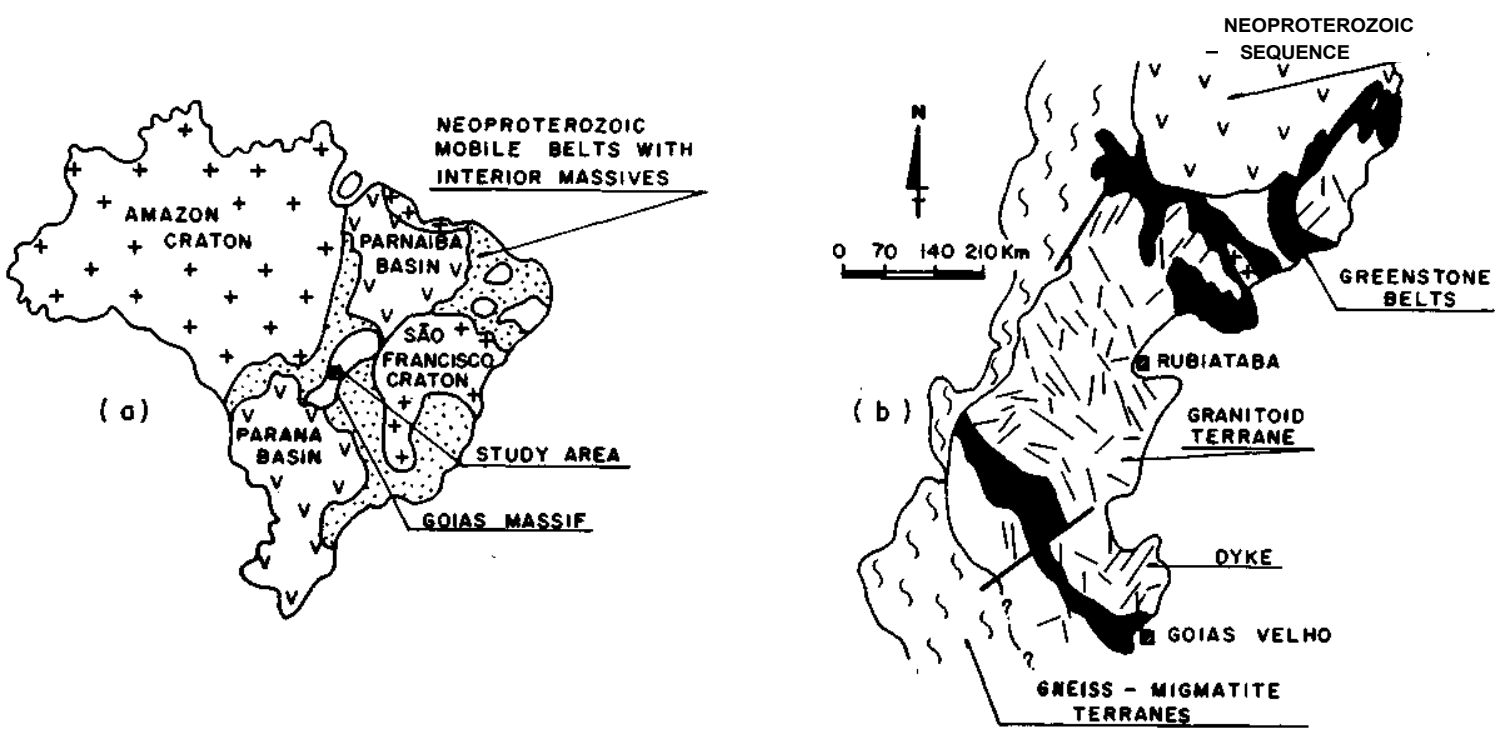

Figure 1 - Simplified geologic map of the Goiás Massifshowing distribution of major dike swarms. (J) gneiss-migmatitic terranes; (2) granitoid terranes and mafic dikes; (3) greenstone belts; (4) Neoproterozoic inagmatic are; (5) Brasília mobile belt and (6) Paraguai-Araguaia mobile belt.

Figura 1 - Esboço geológico do Maciço de Goiás mostrando a distribuição dos principais enxames de diques. (1) terrenos gnáissico-migmatíticos; (2) terrenos granitóides e diques máficos; (3) greentone belts; (4) arco magmático neoproterozóico; (5) Faixa Brasília e (6) Faixa Paraguai-Araguaia.

\section{Table 1 - Representative chemical data of the Goiás Massifmafic dikes. Major and minor elements in \% and trace elements in} ppm.

Tabela 1 - Dados químicos de diques do Maciço de Goiás. Elementos maiores e menores expressos em \%. Elementos traço em ppm.

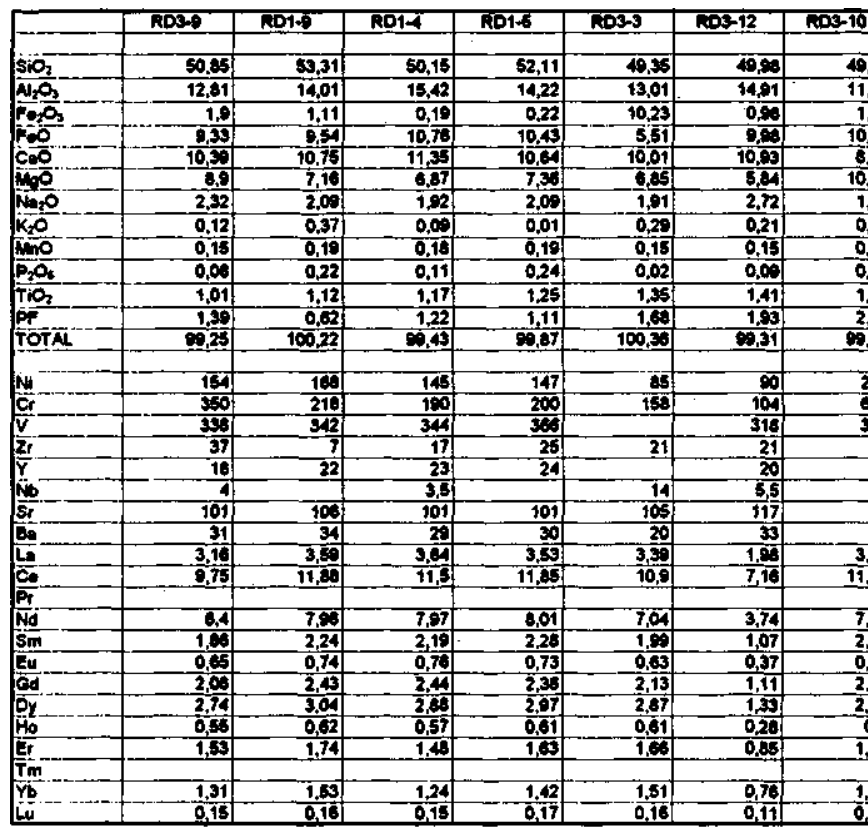

Minor ultramafic dikes composed of different proportions of serpentine, tale, actinolite, chlorite, magnetite/ilmenite, and relics of igneous olivine and clinopyroxene also occur, but are subordinated.

WHOLE-ROCK GEOCHEMISTRY Major and trace elements were determined by inductively coupled plasmaatomic emission spectrometry (ICP-AES) at the Laboratório de Geoquímica of the Instituto de Geociências, Universidade de Brasília. Selected samples were analyzed by ICP-MS for rare earth elements, $\mathrm{Hf}$, Ta, Th, and $\mathrm{Nb}$ at BRGM-Orléans, France. The majority of samples are low in volatiles (LOI), ranging from 0.62 to $2.93 \%$ (average $=1.83 \%$ ). Representative analyses ofthe mafic dikes are presented in Table 1.

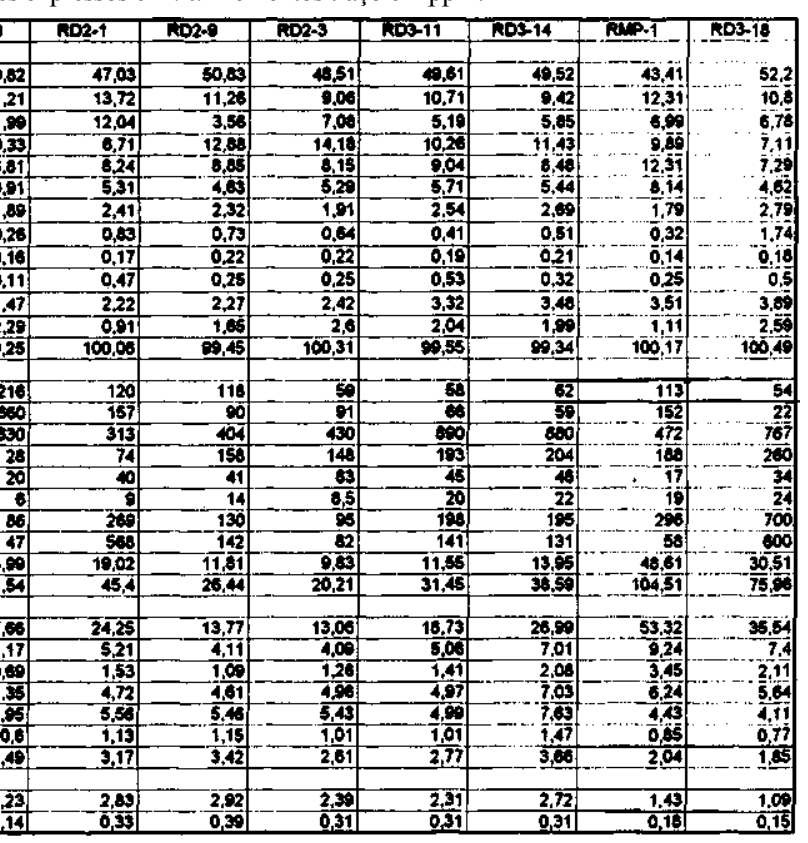

The $\mathrm{SiO}_{2}$ vs $\mathrm{Na}_{2} \mathrm{O}+\mathrm{K}_{2} \mathrm{O}$ (Lê Bass et al. 1986), Ti vs V (Shervais 1982) and $\mathrm{Zr} / \mathrm{P}$ vs Nb/Y (Floyd and Winchester 1975) diagrams show that studied dikes are mostly tholeiitic basalts, with SiÜ2 ranging from 47.03 to $53.31 \%$ and $\mathrm{MgO}$ from 3.72 to $8.90 \%$. As primary mantle-derived tholeiitic melts normally have $\mathrm{mg} \#[\mathrm{MgO} /(\mathrm{MgO}+\mathrm{FeOt})]$ greater than 0.68 and $\mathrm{Ni}$ between 300 and $500 \mathrm{ppm}$, the $\mathrm{mg} \#$ and $\mathrm{Ni}$ contents (0.31-0.62 and 43-210 ppm, respectively) suggest that the mafic dikes from Goiás represent differentiated basaltic magmas.

Major and mainly trace element data indicate the existence of three groups of basalts with almost similar $\mathrm{MgO}$ contents, that differ in the $\mathrm{TiO}_{2}$ content $(<2 \%=$ lower titanium-LTi; $2-3 \%=$ medium titanium-MTi and $>3 \%=$ high titanium-HTi) 

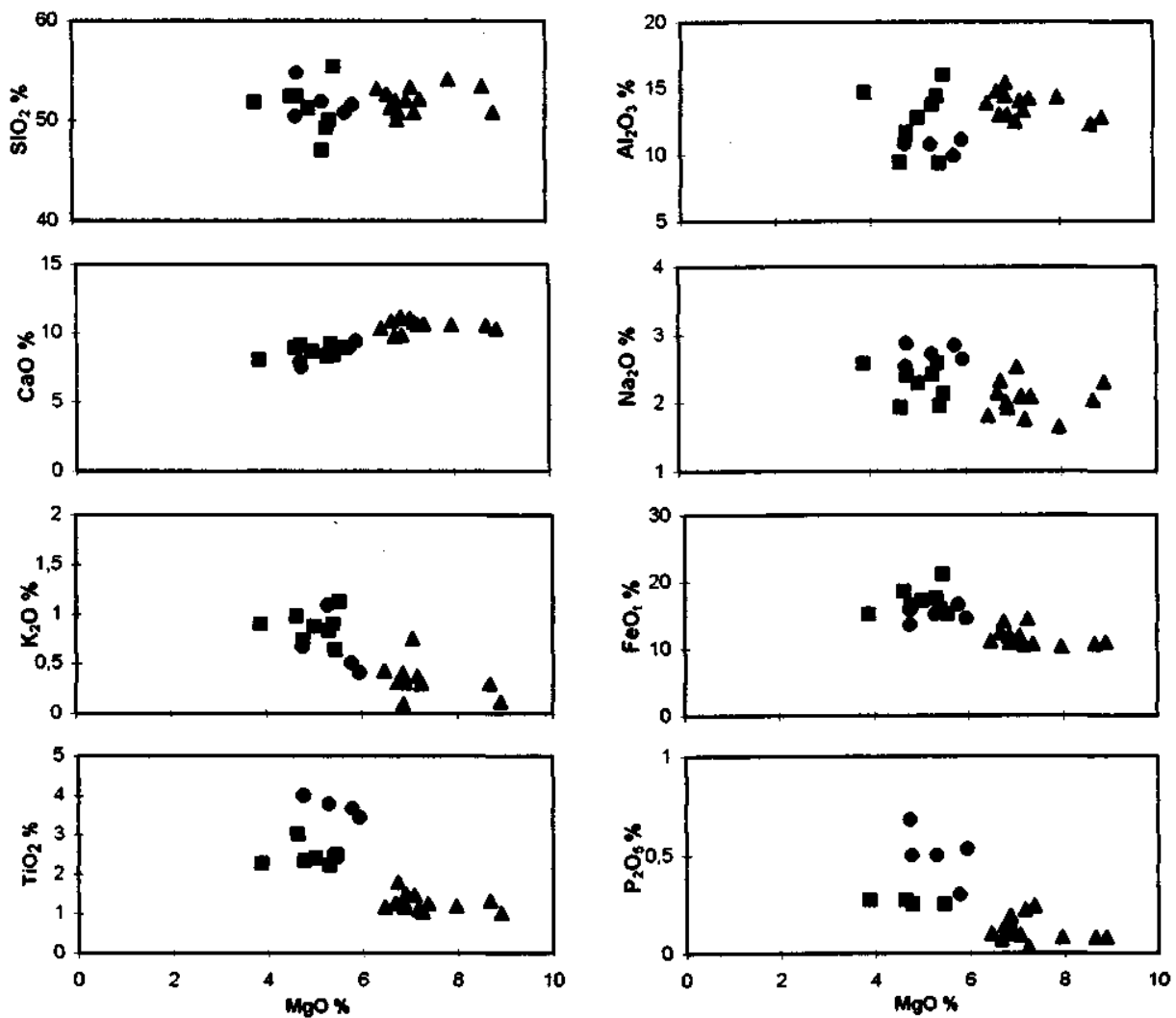

Figure 2 - Major and minor elements of the Goiás Massifmafic dikes plotted against MgO. • HTi-dikes,

\section{A. LTi-dikes}

Figura 2 - Diagrama de elementos maiores e menores versus MgO para os diques máficos do Maciço de Goiás, •diques de alto TiOi, $₫$ diques de TiCh intermediário e $\boldsymbol{\Delta}$ diques de baixo $\mathrm{TiO}_{2}$.
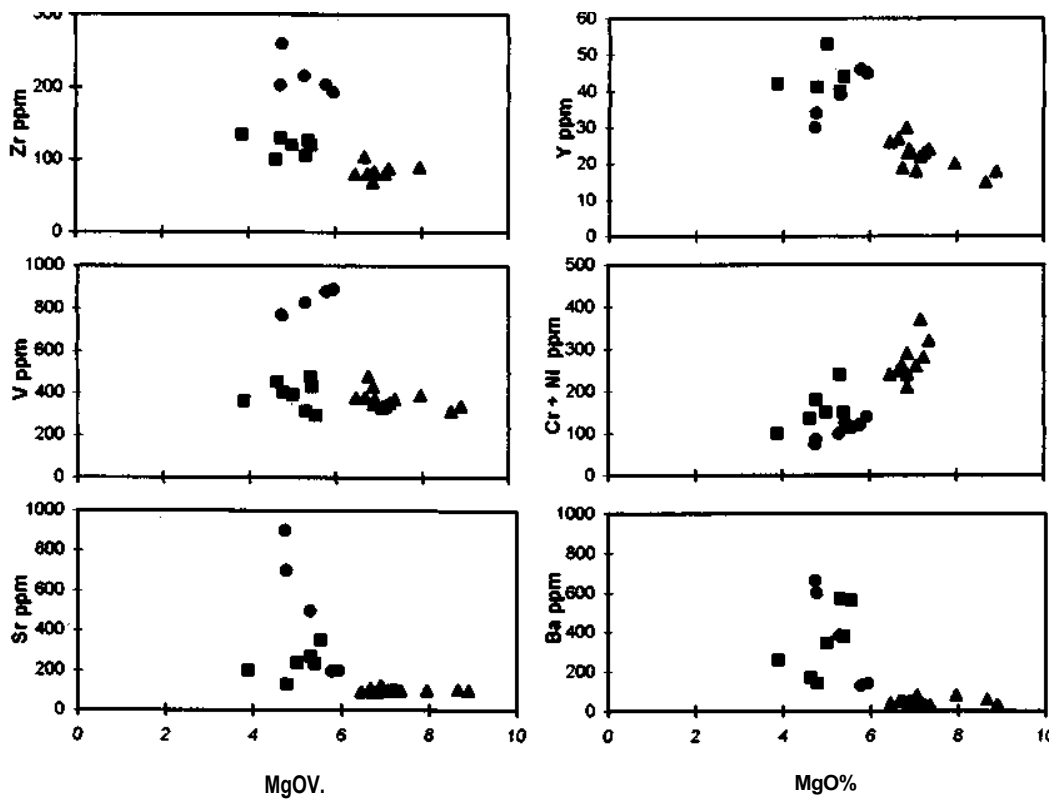

Figure 3 - Trace elements ofthe Goiás Massifmafic dikes plotted against MgO. For legend see Figure 2.

Figura 3 - Diagrama de elementos traço versus MgO para os diques má ficos do Maciço de Goiás. Vide legenda da Figura 2.

and incompatible elements contents $(\mathrm{Zr}, \mathrm{Y}, \mathrm{V}, \mathrm{Cr}, \mathrm{Ni}, \mathrm{Sr}$ and $\mathrm{Ba}$ ). Figures 2 and 3 show that, HTi-dikes generally have higher concentrations of $\mathrm{P}_{2} \mathrm{O}_{5}, \mathrm{TiO}_{2}, \mathrm{~V}, \mathrm{Zr}$ and $\mathrm{Sr}$, and lower contents of AhOs, $\mathrm{Ni}$ and $\mathrm{Cr}$ than the LTi-dikes. The decrease of $\mathrm{Al}_{2} \mathrm{O}_{3}$ with decreasing $\mathrm{MgO}$ contents, and the positive correlation between $\mathrm{CaO}$ and $\mathrm{MgO}$, suggest plagioclase and calcic pyroxene fractionation.
Although a genetic relationship between LTi-, MTi-, and HTi-dikes may be suggested, the variation trends of $\mathrm{TiO}_{2}$, $\mathrm{P}_{2} \mathrm{O}_{5}, \mathrm{Zr}$, and $\mathrm{V}$ show compositional gaps between the three groups of mafíc dikes.

The $\mathrm{TiO}_{2}, \mathrm{P}_{2} \mathrm{O}_{5}, \mathrm{Ni}, \mathrm{Cr}, \mathrm{V}, \mathrm{Y}, \mathrm{Sr}$ and $\mathrm{Ba}$ variations are shown in figure 4 , and $\mathrm{Zr}$ was chosen as a common abscissa for ali plots because it is considered to be good index of 

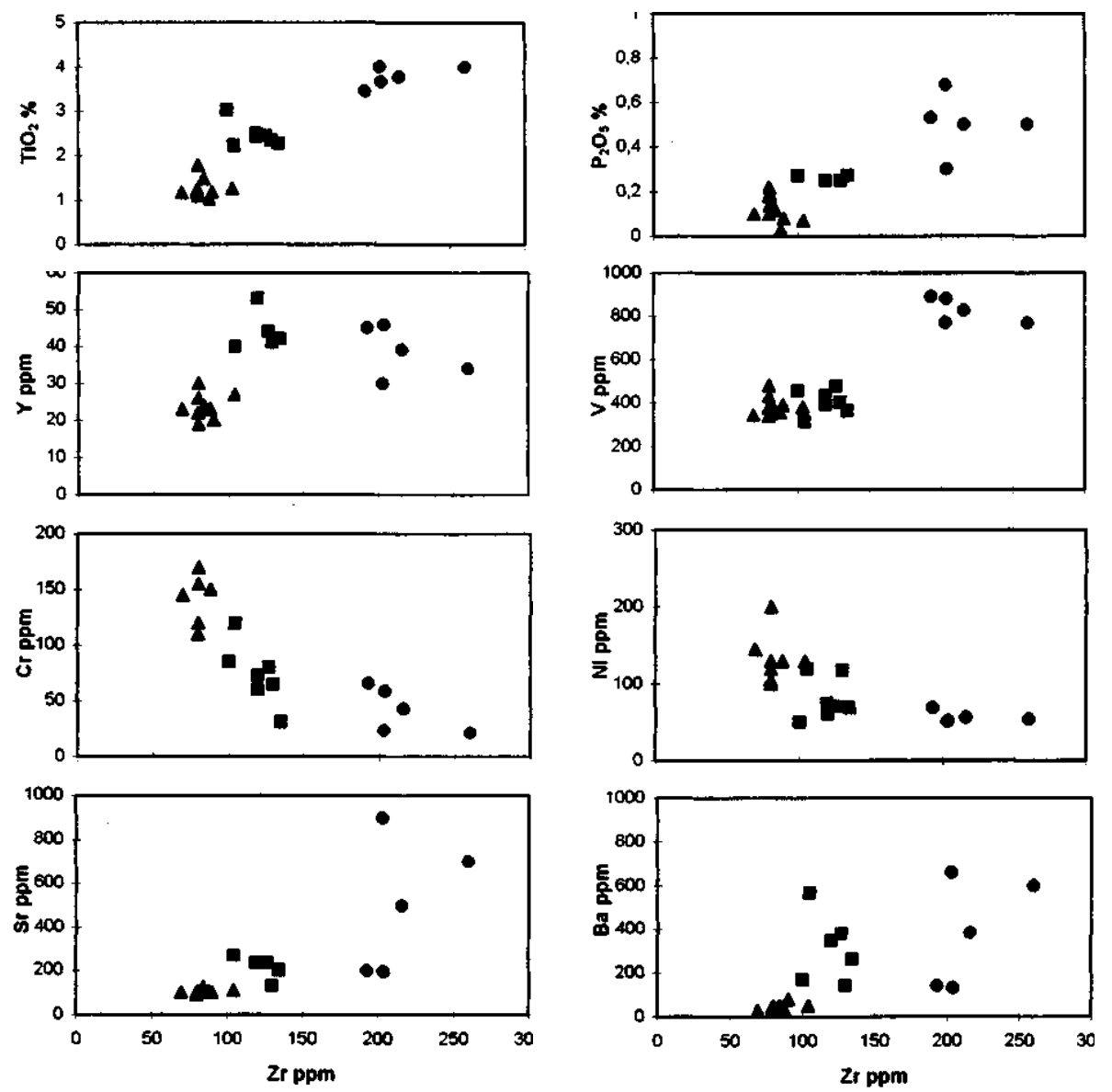

Figure 4-Selected minor and trace elements ofihe Goiás Massifmafic dikes plotted against Zr. For legend see Figure 2.

Figura 4 - Diagrama de elementos menores e traço específicos versus Zr para os diques má ficos do Maciço de Goiás. Vide legenda da Figura 2.

differentiation. Generally, there is a positive correlation bctween $\mathrm{Zr}$ and $\mathrm{Ti}, \mathrm{V}, \mathrm{Y}, \mathrm{Sr}$ and $\mathrm{Ba}$, and a negative correlation between $\mathrm{Zr}$ and $\mathrm{Ni}$ and $\mathrm{Cr}$ between the swarms. Although sharing the characteristics of the other dikes for most elements, the HTi-dikes $\left(>3.0 \% \mathrm{TiO}_{2}\right)$, are richer in $\mathrm{TiO}_{2}, \mathrm{P}_{2} \mathrm{O}_{5}$, $\mathrm{Zr}$, and $\mathrm{V}$. The higher contents of Ti, $\mathrm{P}, \mathrm{Zr}$ and $\mathrm{V}$ can not be explained by different melting degrees of a source of constant composition, fractionation or by cumulus effects, which were not observed in the studied samples, and requires a complementary enrichment in their parent melts. The LTi- and HTidikes have distinct $\mathrm{Zr} / \mathrm{Ti}, \mathrm{Zr} / \mathrm{V}$ and $\mathrm{Zr} / \mathrm{Y}$ ratios.

The LTi- dikes have $\mathrm{Zr} / \mathrm{Ti}$ (average=0.008), $\mathrm{Zr} / \mathrm{V}$ (avcrage $=0.17$ ) and $\mathrm{Zr} / \mathrm{Y}$ (average $=2.47$ ) ratios which are usually lower than those of MTi dikes $(\mathrm{Zr} / \mathrm{Ti}=0.011, \mathrm{Zr} / \mathrm{V}=0.35$ and $\mathrm{Zr} / \mathrm{Y}=3.86)$ and HTi-dikes $(\mathrm{Zr} / \mathrm{Ti}=0.009, \mathrm{Zr} / \mathrm{V}=0.26$ and $\mathrm{Zr} / \mathrm{Y}=5.78)$.

Continental crust is characterized by lower $\mathrm{Ti} / \mathrm{Zr}$ and $\mathrm{P} / \mathrm{Zr}$ ratios $(<54$ and $<4$, respectively) than MORB (59 and 4 , respectively). In mantle normalized plots, crustal contaminated basic rocks would develop pronounced negative anomalies of P and Ti (Weaver \& Tarney 1984). Mafic dikes of the Goiás Massif have $\mathrm{Ti} / \mathrm{Zr}>55$ and $\mathrm{P} / \mathrm{Zr}>5$, and in the mantle normalized multi-element diagram they show absence or small negative anomalies of $\mathrm{Nb}, \mathrm{P}$ and Ti (Figure 6), suggesting small or absence of crustal contamination.

Rare earth element patterns of selected samples are shown in figure 5 . The nearly flat REE patterns of the LTi-dikes $(\mathrm{LaN} / \mathrm{YbN}=1.5$ to 2.16$)$ are similar to the depleted Archaean tholeiitic basalts and to mid-ocean ridge basalts (MORB), particularly to some tholeiitic basalts from the FAMOUS área (Langmuir et al. 1977), the Mid-Atlantic Ridge (Schilling
1975) and from the Southwest Indian Ridge (LeRoex et al., 1983). The patterns of MTi- and HTi-dikes show modest fractionation $\left(\mathrm{La}_{\mathrm{N}} / \mathrm{Yb}_{\mathrm{N}}\right.$ 3.43-4.50) resembling continental floor basalts (Basaltic Volcanism Study Project 1981). Ali samples have a small negative Eu anomaly, normally indicative of plagioclase removal.

Figure 6 presents primordial mantle normalized multi-element plols of the studied mafic dike samples compared with avcragcd published data of ocean-island basalt, mid-ocean ridge basalts, and continental flood basalts, plotted for comparison. Paraná and Deccan flood basalts are included as rcpresentatives of continental magmatism, as being derived from lithospheric (Hawkesworth et al. 1988) and asthenospheric (Lightfoot \& Hawkesworth 1988) mantle sources, respectively. The LTi-dikes have almost flat multi-element patterns, displaying enrichment of $\mathrm{Zr}$ with respect to $\mathrm{P}$ and $\mathrm{Y}$, and small negative $\mathrm{K}$ anomalies closely resembling $\mathrm{N}$ MORB. These suggest that the magmas probably derived from a depleted asthenospheric upper-mantle source. The absence of negative $\mathrm{Nb}$ anomalies limits the amount of crustal contamination. Although the HTi-dikes are most enriched in incompatible trace elements than the MTi- dikes, they display almost identical multi-element patterns, similar to the Deccan continental basalts, from which they differ only in the positive $\mathrm{K}$ anomalies in the MTi-dikes, negative $\mathrm{Nb}$ anomalies in the MTi-dikes and lack or very small negative $\mathrm{Nb}$ anomalies in the HTi-dikes. The incompatible element $\mathrm{Zr} / \mathrm{Y}$ and $\mathrm{Zr} / \mathrm{Nb}$ ratios of MTi- (3.65 and 7.0, respectively) and HTi-dikes (4.14 and 19.45 , respectively) are comparable to the same ratios in the T-MORB (3.35 and 13.80, respectively) and Deccan basalts (4.06 and 12.69, respectively). The MTi-dikes multi- 

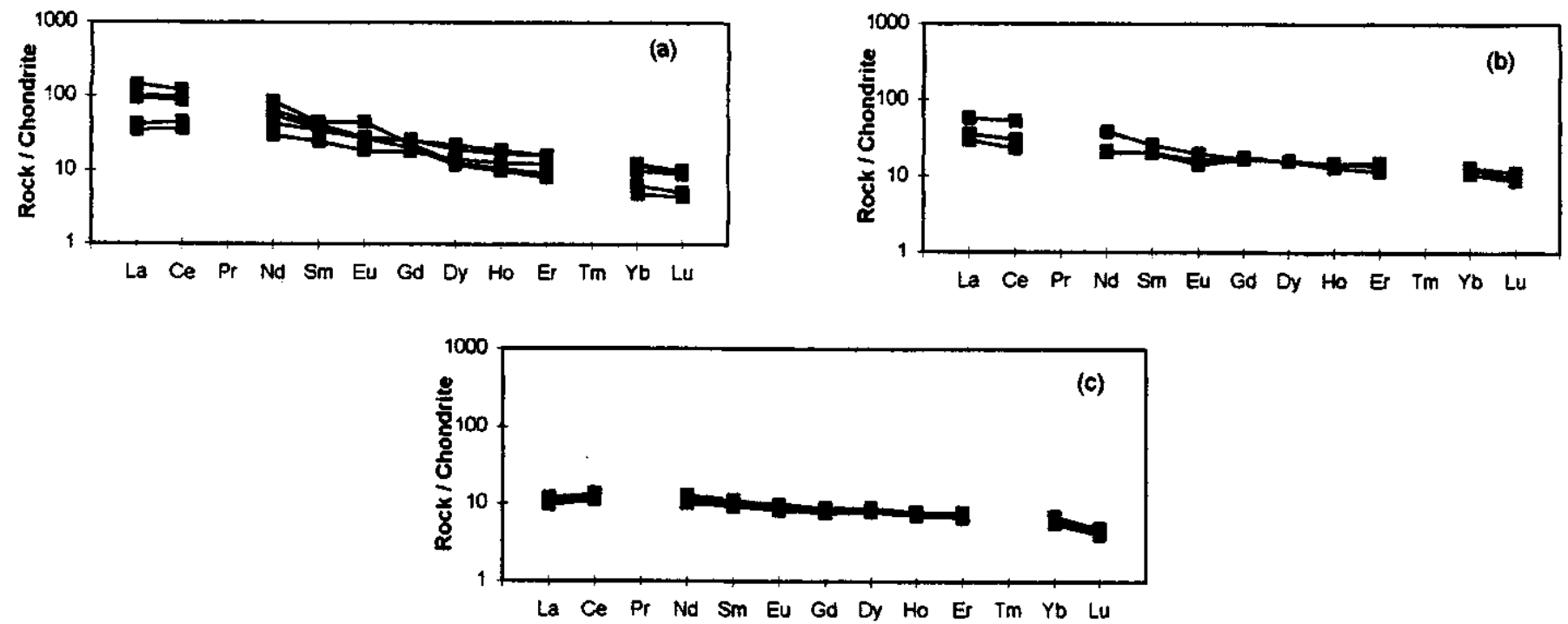

Figure 5 - Rare ecirth elementpatterns of representaíive Goiás Massifnwfic clikes. (a) >3\% TiO $\mathrm{O}_{2}$ dikes; (b) 2-3\% TiO dikes and $>2 \% \mathrm{TiO}_{2}$ dikes. Nonnalizing valites after Nakamura (1974).

Figura 5 - Padrões de elementos terras raras de amostras representativas dos diques máficos do Maciço de Goiás, (a) diques $\operatorname{com}>3 \% \mathrm{TiO}_{2}$; (b) diques com 2 a $3 \% \mathrm{TiO}_{2}$ e diques com $>2 \% \mathrm{TiO}_{2}$. Fatores de normalização recomendados por Nakamura (1974).
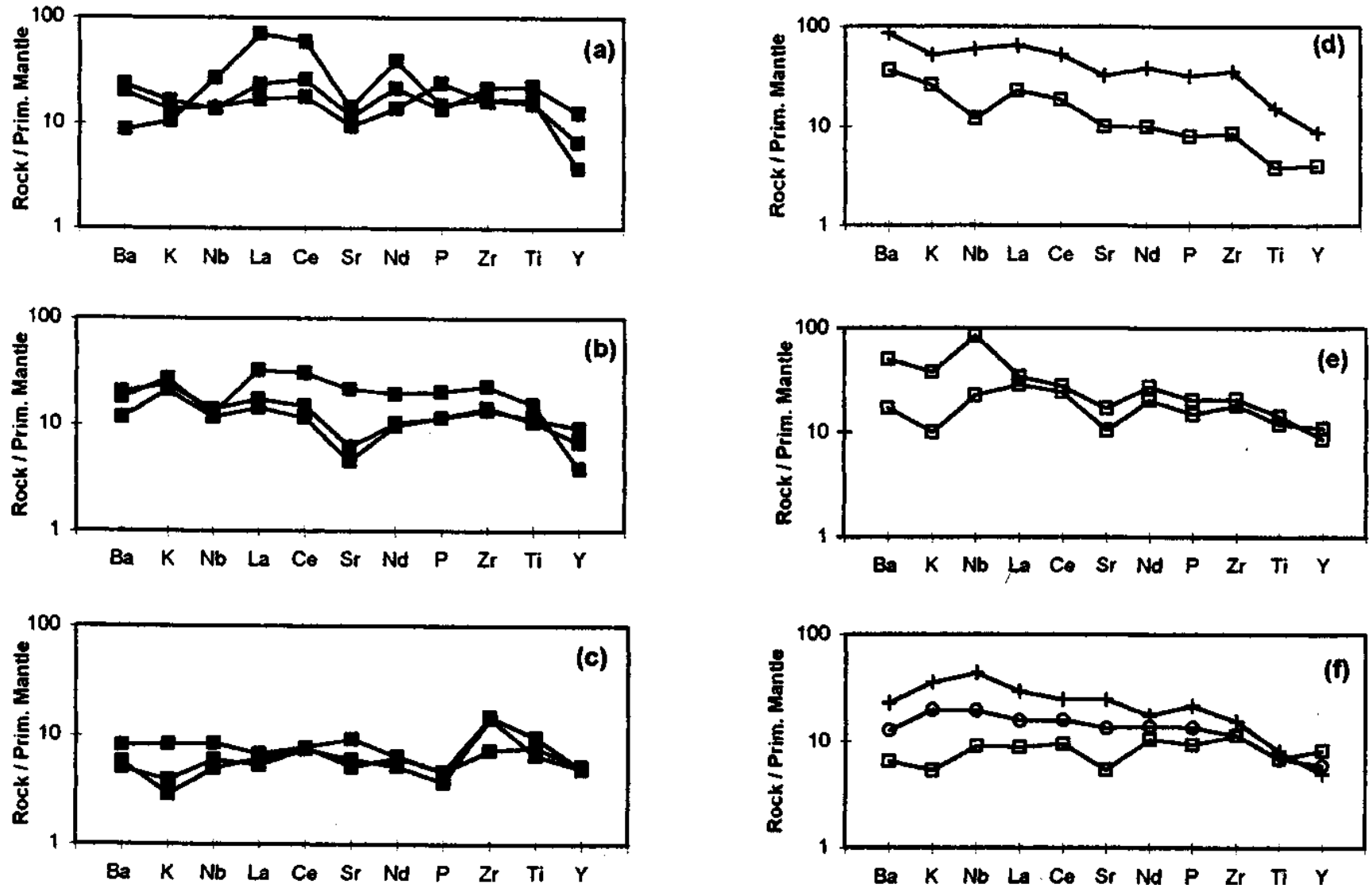

Figure 6 - Primitive mantle-normalized multi-element plofs of representative Goiás Massifmafic dikes. (a) 3\% TiO $;$; (b) 2-3\% $\mathrm{TiO}_{2}$ and (c) $>2 \% \mathrm{TiO}_{2}$; (d) + High- and $\mathrm{O} \mathrm{Low}-\mathrm{TiO}_{2}$ Paraná continental flood basalts (Bellieni et al 1986); (e) $\square$ Deccan continental flood basalts (Lighfoot \& Hawkesworth 1988); (f) $\square$ N-MORB (Lê Roex et al. 1983), (O) T-MORB (Lighfoot \& Hawkesworth 1988) and + P-MORB (Lê Roex et al. 1985). Normalizing valuesfrom Sun \& McDonough (1989). Figura 6 - Diagrama multi-elementar normalizado a manto primitivo para os diques máficos do Maciço de Goiás, (a) $>3 \% \mathrm{TiCh}$; (b) $2-3 \% \mathrm{TiO}_{2}$ e (c) $<2 \% \mathrm{TiO} \mathrm{O}_{2}$; (d) basaltos de derrames continentais com alto $(+)$ e baixo $(\square) \mathrm{TiO}_{2}$ da Bacia do Paraná (Bellieni et al. !986); (e) $\square$ basaltos de derrames continentais da Bacia do Deccan (Lighfoot \& Hawkesworth 1988); $\square$ N-MORB (Lê Roex et al. 1983), (o) T-MORB (Lighfoot \& Hawkesworth 1988) e + P-MORB (Lê Roex et ai. 1985). Fatores de normalização indicados por Sun \& McDonough (1989). 
element patterns more closely resemble T-MORB. The negative $\mathrm{Nb}$ anomalies in the HTi- and mainly in the MTi-dikes indicate that the astenospheric melts interacted with the subcontinental lithosphere or were contaminated by continental crust. Therefore, the MTi- and the HTi-dikes may have had an evolutionary history similar to that suggested for the Deccan basalts, i.e. derivation from asthenospheric sources followed by the interaction with sub-continental lithospheric mantle and small crustal contamination.

CONCLUSIONS Geological and geochemical evidence indicate that at least two mafic dike swarms were emplaced in the Goiás Massif: the first, consisting of low-titanium basalts, hás a composition similar to depleted asthenospheric mantle derived N-MORB, and were probably emplaced during the Archaean and/or Lower Proterozoic as they are overlain unconformable by Middle Proterozoic metasediments. The second, consisting of higher-titanium basalts $(>2 \% \mathrm{TiOz})$, hás geochemical characteristic similar to the continental flood basalts from the Deccan Basin.

Dikes with concentrations with $\mathrm{TiO}_{2}$ varying from 2 to $3 \%$ crosscut the Goiás Massif precambrian terranes and have been affected by shearing during regional compression that took place at the end of the Brasiliano/Pan African Neoproterozoic cycle. The intrusion of these dikes probably occurred during late stages of the Brasiliano deformation $(\sim 600 \mathrm{Ma})$. None of the younger dikes $\left(\mathrm{TiO}_{2}>3 \%\right)$ seem to have been affected by deformation and it is suggested that they correlate with the Mesozoic Paraná Province magmatism, revealing significant chcmical diversity within individual provinces due to heterogeneity of the mantle sources and crustal contamination. If this is correct, the younger dikes are associated with the break-up of the Gondwanaland supercontinent during the Jurassic and Cretaceous, preceding the opening of the South Atlantic Ocean at the latitude of the Tristan da Cunha hot spot (cf. Hawkesworth et al. 1986 and Fodor 1987).

Il hás been suggested that lhe Mesozoic mantle inherited its geochemical and isolope features from processes that occurred during the Proterozoic (Mantovani et al. 1987, Hawkesworth et al. 1988, Oliveira and Tarney 1990 and Mazzucchelli el ai. 1995). The geochemical similarities beIween lhe Neoproterozoic MTi- and the Mesozoic (?) HTidikes from lhe Goiás Massif supporl lhal possibility.

Acknowledgements: Financial support for field visits and lab work was provided through Conselho Nacional de Desenvolvimento Científico e Tecnológico grant $\mathrm{N}^{\circ}$ 500203/92-0.

\section{REFERENCES}

Araújo Filho, J.O. de. 1992. The Pireneus mega-inflection in Central Brazil: an example of a poly-deformed Brasiliano fold-thrust bclt. In: Geowissenschaftliches Lateinamcrika Kolloquium, Munstcr. Abstracts. p. 129.

Basaltic Volcanism Study Project. 1981. The Basaltic volcanism on terresírial planeis, l ed. New York, Pergamon, $1286 \mathrm{p}$.

Bellieni, G.; Comin-Chiaramonti, P.; Marques, L.S.; Melfi, A.J.; Nardy, A.J.R.; Papatrechas, C.; Piccirillo, E.M.; Roisemberg, A.; Stolfa, D. 1986. Petrogenetic aspects of acid and basaltic lavas from the Paraná Plateau (Brazil): geological, mineralogical and petrological relationships. J. Petrol., 27:915-944.

Fodor, R.V. 1987. Low- and high-TiÜ2 flood basalts of soulhern Brazil: origin from picritic parentage and a common mantle source. Earth Planei. Sei. Leu., 84:423-430.

Fuck, R.A.; Montalvão, R.M.G., Bezerra, P.E.L.; Pimentel, M. 1985. Precambrian dyke swarm in central Brazil. In: Internacional Conference on Mafic Dike Swarms, Canadá. Abstracts, p.45.

Floyd , P.A.; Winchester, J.A. 1975. Magma type and tectonic setting discrimination using immobile elements. Earth Planei. Sei. Lett., 27:211-218.

Girardi, V.A.V.; Mazzucchelli, M.; Molesini, M.; Finatti, M.C.; Rivalenti, G.; Correia, C.T. 1992. Petrological and geochemical aspects of mafic dykes of the Goiás, state, Brazil. In: SBG, Congr. Brás. Geol., 37, São Paulo. Anais, 1:490-495.

Hawkesworth, C.J.; Mantovani, M.S.M.; Peate, D. 1988. Lithosphere remobilization during Paraná CFB magmatism. J. Pelrol., Special Lithosphere Issue. p. 205-223.

Hawkesworth; C.J.; Mantovani, M.S.M.; Taylor, P.N.; Palacz, Z. 1986. Evidence from the Paraná ofsouth Brazil for a continental contribution to Dupal basalts. Nature, 322:356-359.

Kuyumjian, R.M. 1991. Mafic dyke swarms in Goiás, central Brazil. In: International Symposium on Mafic Dykes, São Paulo. Exlended Abslracts, 51-54.

Langmuir, C.H.; Bender, J.F.; Bence, A.E.; Hanson, G.N.; Taylor, S.R.. 1977. Petrogenesis of basalts from the Famous área: Mid-Atlantic Ridge. Earth Planei. Sei. Lett., 36:133-156.

Lê Bas, M.J.; Lê Maitre, R.W.; Streckeisen, A.; Zanettin, B. 1986. Chemical classification of volcanic rocks based on the total alkali-silicadiagram. J. Petrol., 27:745-750.

Lê Roex, A.P.; Dick, H.J.B.; Erlank, A.J.; Reid, A.M.; Frey, F.A.; Hart, S.R. 1983. Geochemistry, mineralogy and petrogenesis of lavas erupted along the Southwest Indian Ridge between the Bouvet triple junction and 11 degrees East. J. Petrol., 24(3):267-318.
Le Roex, A.P.; Dick, H.J.B.; Reid, A.M.; Frey, F.A. Erlank, A.J.; Hart, S.R. 1985. Petrology and geochemistry of basalts from the American-Antartic ridge, Southern Ocean: implications from the wcstward influence of the Bouvet mantle plume. Contrib. Mineral. Petrol., 90:367-380.

Lighfoot, P., Hawkesworth, C.. 1988. Origin of Deccan Trap lavas: evidence from combined trace element and $\mathrm{Sr}-, \mathrm{Nd}-$ and $\mathrm{Pb}$-isotope studies. Earth Planei. Sei. Lett., 91: 89-104.

Mazzucchelli, M.; Rivalenti, G.; Piccirillo, E.M.; Girardi, V.A.V · Civetta, L. \& Petrini, R.. 1995. Petrology of the Proterozoic mafic dyke swarms of Uruguay and constraints on their mantle source composition. Prec.Res., 4: 177-194.

Nakamura, N. 1974. Determination of REE, Fe, Mg, $\mathrm{Na}$ and $\mathrm{K}$ in carbonaceous and ordinary chondrites. Geoch. Cosmoch. Acta, 38:757-775.

Oliveira, E.P.; Tarney, J.. 1995. Petrogenesis of the Late Proterozoic Curaçá mafic dyke swarm, Brazil: asthenospheric magmatism associated with continental collision. Mineral. Petrol., 53: 27-48.

Schilling JG. 1975. Rare-earth variations across normal segments of the Reykjanes Ridge, $60^{\circ}-53^{\circ} \mathrm{N}$, Mid-Atlantic Ridge, $29^{\circ} \mathrm{S}$, and East Pacific Rise, $2^{\circ}-19^{\circ} \mathrm{S}$, and evidence on the composition of the underlying low- velocity layer. /. Geophys. Rés., 87:5593-5610.

Shervais, J.W.. 1982. The Ti-V plots and the petrogenesis of modern and ophiolitic lavas. Earth Planei. Sei. Lett., 59:101-118.

Sial, A.N.; Oliveira, E.P.; Choudhuri, A.. 1987. Mafic dyke swarms of Brazil. In: H.C. Halls, H.C. \& W.F. Fahrig.(ed.) Mafic Dyke Swarms. Geol. Assoe. Can., Spec. Pap., 34:467-481.

Sun, S.S.; McDonough, W.F. 1989. Chemical and isotopic systematics of oceanic basalts: implications for mantle composition and processes. In: A.D. Saunders; M.J. Norry (ed.) Magmatism in the ocean basins. Oxford. Geol. Soe. Spec. Publ., 42: 313-345.

Tomazzoli, E.R.. 1992.0 greenstone belt de Goiás: estudos geocronológicos. Rev. Brás. Geoc., 22(1):56-60.

Tomazzoli, E.R.\& Nilson, A.A.. 1994. Diques máfico-ultramáficos de Goiás: aspectos petrológicos. In: SBG, Congr. Brás. Geol., 38, São Paulo. Anais, 1:63-65.

Valente, C.R.; Kuyumjian, R.M.. 1992. Análise da cinemática dos diques máficos antigos de Goiás: estudo a partir de imagens de satélite. In: SBG, Brazilian Remote Sensing Symposium, 4, Curitiba. Anais, 2:351-357.

MANUSCRITO A-939 Recebido em 06 de outubro de 1997 Revisão dos autores em 10 de janeiro de 1998 Revisão aceita em 20 de janeiro de 1998 